\title{
Comparative Performance Analysis of Three Parameter Estimation Methods for Two Parameter Weibull Distribution in Wind Speed Assessment
}

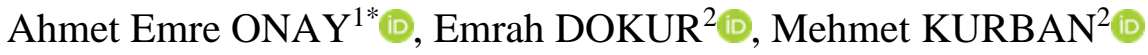 \\ ${ }^{1}$ Bilecik Seyh Edebali University, Department of Energy Systems Engineering \\ ${ }^{2}$ Bilecik Seyh Edebali University, Department of Electric Electronics Engineering
}

Geliş / Received: 28/01/2021, Kabul / Accepted: 01/06/2021

\begin{abstract}
The two-parameter Weibull distribution is widely used in the estimation of wind speed. In this paper, some recently proposed parameter estimation methods for the two parameter Weibull distribution have been compared using the wind data from two cities in Turkey. The compared methods in this paper are Wind Energy Intensification Method (WEIM), Energy Pattern Factor Method (EPFM), and Power Density Method (PD). These methods have been compared by checking the fit have provided in the probability-density graph. The comparison has also been made by comparing of efficiencies these methods in predicting wind energy density. Lastly, a comparison has been investigated by using the following performance criteria; Wind Energy Error (WEE), Root Mean Square Error (RMSE), Coefficient of Determination $\left(\mathrm{R}^{2}\right)$, and the results of error analysis have been compared. According to simulation results, while the EPFM and PD methods have shown a very close fit on the graph; when it comes to calculating wind energy densities, the PD method has shown a significant advantage over other methods. Finally, after the examination of error criteria, it was clear that EPFM has shown accurate performance which is the desired result. The main conclusion is that the accurate method for these selected regions is the EPFM.
\end{abstract}

Keywords: Wind energy, Parameter estimation, Weibull distribution, EPFM, PD, WEIM.

\section{Rüzgar Hızı Değerlendirmesinde İki Parametreli Weibull Dağılımı İçin Üç Parametre Tahmin Metodunun Karşılaştırmalı Performans Analizi}

\section{Öz}

İki parametreli Weibull dağılımı rüzgâr hızı tahmininde yaygın bir şekilde kullanılmaktadır. Bu çalışmada, iki parametreli Weibull dağılımı için yakın zamanda önerilmiş belirli parametre tahmin metotları, Türkiye'nin iki ilinin rüzgâr verileri kullanılarak karşılaştırılmışır. Bu çalışmada kullanılan metotlar; Rüzgâr Enerjisi Yoğunlaştırma metodu (WEIM), Enerji Örüntü Faktörü metodu (EPFM) ve Güç Yoğunluğu metodudur (PD). Bu metotların olasıllk-yoğunluk grafiğindeki uyumları karşılaştırılmıştır. Ayrıca, bu metotların, rüzgâr enerjisini tahmin etmedeki performansları da karşılaştırılmıştır. Son olarak, belirtilen performans kriterleri kullanılarak bir karşılaştırma yapılmıştır; Rüzgâr Enerji Hatası (WEE), Ortalama Karekök Hatası (RMSE), Belirleme Katsayısı $\left(\mathrm{R}^{2}\right)$. Sonuç olarak, EPFM ve PD metotları grafik üzerinde oldukça yakın bir uyum gösterirken, rüzgâr enerji yoğunluklarını hesaplamada PD metodu önemli bir fark göstermiştir. Ayrıca, hata performansları incelendikten sonra, istenen sonuçlara EPFM tarafindan ulaşıldığı görülmüştür. Sonuç olarak, bu çalışmada istenen sonuca yakın değerler veren metodun Enerji Örüntü Faktörü metodu olduğu görülmüştür.

Anahtar Kelimeler: Rüzgâr enerjisi, Parametre tahmini, Weibull dağılımı, EPFM, PD, WEIM.

\footnotetext{
*Corresponding Author: 1149435@ogrenci.bilecik.edu.tr
} 


\section{Introduction}

The increasing use of renewable resources has also been increasing the demand for the installation and future planning of electricity generating plants that use renewable energy sources such as solar, hydro, and wind power.

The wind energy potential of Turkey has been proving itself especially in the coastal regions and in the elevated areas of the country (Enerji Atlas1, 2021). Since there is an increasing demand for clean energy, the amount of planning required for the installation of renewable power plants has gained a lot more importance. Especially in the wind power sector, the required planning is vital for the future energy production of a wind power plant that is planned to be installed in a specific location.

There is a need to determine how much wind any power plant will take in a certain time horizon in the future. At this point, some tools like Weibull, Burr, or Rayleigh distributions come in. These distributions help predict the amount of wind speed at a certain time in the future, by using past wind speed data.

Lots of estimation methods are proposed for two parameter Weibull distribution in the literature. In one of these studies, Chang (2011) has compared six methods namely Moment Method (MOM), Justus Moment Method (JMM), Graphical Method (GM), Maximum Likelihood Method (MLM), Modified Maximum Likelihood Method (MMLM), and Energy Pattern Factor Method (EPFM). The comparison results presented that the GM has provided the least suitable results. In addition, it has been stated that all six methods have resulted in acceptable range in the case of the wind speed showing a good fit with the Weibull function. This study has also indicated that MLM, and then MMLM has shown good performances.

Kidmo et. al. (2015), have comparatively analyzed six methods namely JMM, EPFM, GM, MLM, MOM, and MMLM. According to the results, the EPFM and then the MOM has shown the best and the most efficient results in the prediction of the shape (k) and scale (c) parameters.

There are many other instances where similar studies have taken place in Turkey, where this paper has also focused on. In their study, Akdağ and Dinler (2009), have compared the GM, MLM, MOM, and Power Density Method (PD) for Maden, Gökçeada, Çanakkale, and Bozcaada regions. The results have shown that the PD method is adequate for parameter estimation for the Weibull distribution.

In this paper, the two-parameter Weibull distribution and three methods used to estimate the parameters of this distribution have been studied. These two parameters need to be determined in order to make a proper estimation. This paper aims to compare three estimation methods namely Wind Energy Intensification method (WEIM), Energy Pattern Factor method (EPFM), and Power Density method (PD). The study presents the difference, if any, between the parameter estimation by using the data from two regions with different levels of wind energy densities. The comparisons have been made using three years of hourly wind data for two cities, Bilecik and Kütahya in Turkey. The results present the difference between two cities from separate regions of Turkey which have different levels of wind energy densities. In some cases, certain methods show variance in their parameter estimations depending on the wind density. This is one of the reasons mentioned cities have been used in this study. After a three-step comparison, the method with the most satisfactory results in predicting the parameters of the Weibull distribution are determined. The three-step comparison is as follows; i) The fit which has been provided by the methods in the probability-density graph has been observed and 
compared, ii) The efficiencies of these methods in calculating the wind energy densities have been compared, iii) The error values of these methods that have been calculated using Wind Energy Error (WEE), Root Mean Square Error (RMSE), and Coefficient of Determination $\left(\mathrm{R}^{2}\right)$ have also been compared, and these methods have been ranked according to their performances.

\section{Material and Methods}

\subsection{Wind Data}

The wind data for this study has been acquired from SolarRadiationData's website (SolarRadiationData, 2021). The data from this source consists of three years of hourly wind data at 10-meter height. The required height for this study was 50 meters. For meaningful analysis of the data, they were rearranged for $50 \mathrm{~m}$ height using power law. The wind data of this study belongs to Bilecik and Kütahya cities in Turkey. Figure 1 shows the comparison of the wind energy densities of these two cities.

\subsection{Power Law}

Since the wind data was not of the desired height, one of the tools to convert the wind data at different heights has been used. This tool is called Power Law and described in Equation (1) (Secci and Gualtieri, 2011).

$$
v_{2}=v_{1}\left(\frac{h_{2}}{h_{1}}\right)^{\alpha}
$$

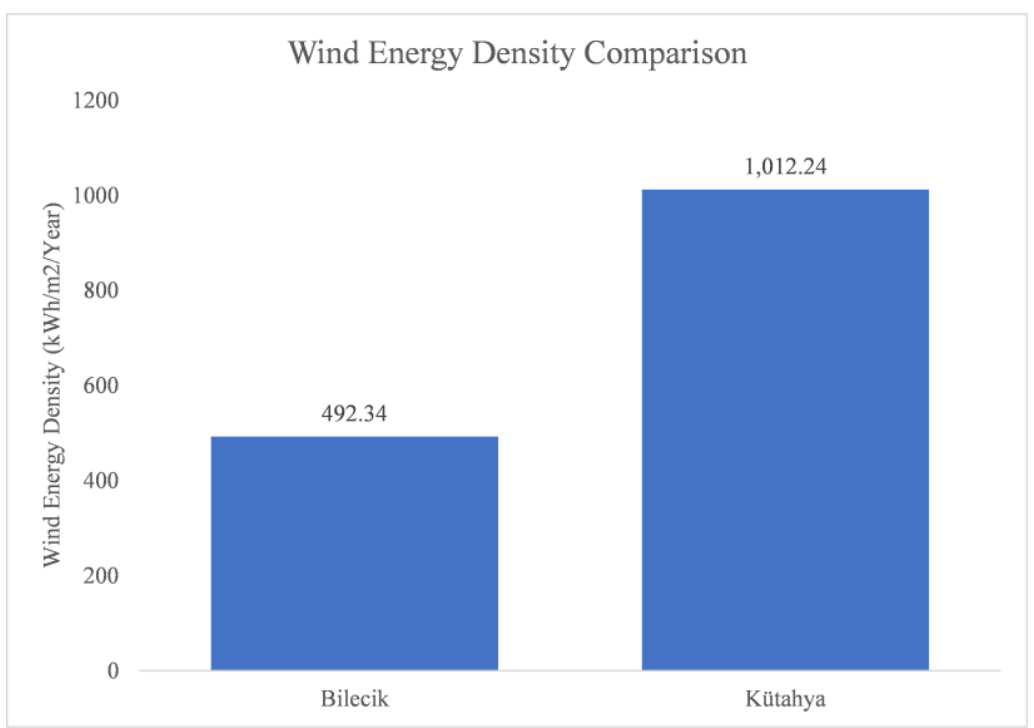

Figure 1. The wind energy densities of the studied cities

In (1), $v_{2}$ is the wind speed at the desired height $h_{2}$, and $v_{l}$ is the wind speed at the known height $h_{1}$. The $\alpha$ value is called the Hellman exponent. This value ranges from 0.40 to 0.10 depending on the location of the wind speed data (Bañuelos-Ruedaset al, 2010). The widely used value for $\alpha$ in the world is $1 / 7$ (0.143) (Counihan, 1975). 


\subsection{Two-Parameter Weibull Distribution}

The probability density function of the Weibull distribution is shown in (2).

$$
f(v)=\left(\frac{k}{c}\right)\left(\frac{v}{c}\right)^{k-1} e^{\left(-\frac{v}{c}\right)^{k}}
$$

In (2), the $f(v)$ value is the Weibull function that is calculated for any wind speed. That is also the probability to observe wind speed. The two parameters that are estimated for the Weibull distribution are the shape $(k)$ and the scale $(c)$ values (Akpinar and Akpinar, 2005). Some different methods have been used to calculate these parameters. Three of these methods have been used in this study.

The cumulative density function of the Weibull distribution can be seen in (3).

$$
F(v)=1-e^{-\left(\frac{v}{c}\right)^{k}}
$$

In (3), $F(v)$ value is the cumulative distribution function (Dokur and Kurban, 2015).

\subsection{Weibull Parameter Estimation Methods}

\subsubsection{Wind Energy Intensification Method (WEIM):}

This method has been proposed recently by Sumair et al. (2020) in the literature. WEIM relies on two factors; i) calculation of a scale factor which is given in (5), and ii) the difference between average power of the wind and power of average wind. This factor is named Wind Energy Intensifier (WEI).

There are some similarities between this method and the Energy Pattern Factor method. Both methods call for the calculation of a value that is dependent on the cubed wind speed. In this method, this value is called WEI, and it is expressed in Equation (4). The calculation of the parameters of this is described in (5) and (6).

$$
\begin{aligned}
& A=W E I=\frac{\frac{1}{2} \rho \bar{v}^{3} T}{\frac{1}{2} \rho \overline{v^{3}} T}=\frac{\left[\int_{0}^{\infty} v f(v) d v\right]^{3}}{\int_{0}^{\infty}[v f(v) d(v)]^{3}} \\
& c \propto \bar{v} \rightarrow c=A \bar{v} \\
& \ln c=\frac{1}{k} \ln \overline{v^{k}} \rightarrow \ln c-\frac{1}{k} \ln \overline{v^{k}}=0
\end{aligned}
$$




\subsubsection{Energy Pattern Factor Method (EPFM):}

This method is based on mean wind speeds and firstly requires a value called Energy Pattern Factor (Epf) to be calculated. Then, shape $(k)$ and scale $(c)$ values can be calculated using this value that could be seen in (7) (Usta et al., 2018).

$$
\begin{aligned}
& E p f=\frac{\overline{v^{3}}}{(\bar{v})^{3}}=\frac{\Gamma(1+3 / k)}{\Gamma(1+1 / k)^{3}} \\
& k=1+\frac{3.69}{E p f^{2}} \\
& c=\frac{\bar{v}}{\Gamma\left(1+\frac{1}{k}\right)}
\end{aligned}
$$

\subsubsection{Power Density Method (PD):}

This method incorporates the Epf value that was calculated in (7) to determine the shape value in (10). Then the shape value is used to calculate the scale value in (11), which is the same formula used in (9) (Chaurasiya et al., 2018).

PD method has simple formulation, does not require any wind speed classes or an iterative approach, and in the case where power density and mean wind speed is available, it is very easy to estimate Weibull parameters, and as it can be seen in Figure 4, it is an accurate tool to calculate wind power densities (Akdağ and Dinler, 2009).

$$
\begin{aligned}
& \frac{\Gamma(1+3 / k)}{\Gamma^{3}(1+1 / k)}-E p f=0 \\
& c=\frac{\bar{v}}{\Gamma\left(1+\frac{1}{k}\right)}
\end{aligned}
$$

\subsection{Wind Energy Density}

In this paper, the actual wind energy densities of the cities and the wind energy densities that have been calculated using the parameter estimation methods for these cities have been compared for their accuracies. Wind energy density calculation for the parameter estimation methods is described in (12).

$$
W E D=\left[\frac{1}{2} \rho \int_{0}^{\infty} v^{3} \cdot\left(\frac{k}{c}\right)\left(\frac{v}{c}\right)^{k-1} e^{\left(-\frac{v}{c}\right)^{k}} d(v)\right] T=\left[\frac{1}{2} \rho c^{3} \Gamma\left(1+\frac{3}{k}\right)\right] T
$$


Equation (12) describes $v$ as wind speed value, $k$ and $c$ as scale and shape values, respectively, and $T$ as time in hours (Sumair et al., 2020).

\subsection{Performance Criteria}

The performances of the three methods that have been used in this study have been compared to determine the method that gives the most accurate and efficient results.

\subsubsection{Wind Energy Error:}

There is a difference between the wind energy density calculated using actual wind speed values and the wind energy density calculated using the Weibull distribution. Equation (13) shows the error value between these two calculations (Sumair et al., 2020).

$$
W E E=\left|\frac{W E D_{W}-W E D_{a c t}}{W E D_{a c t}}\right|
$$

Here, while $W E D_{w}$ shows the wind energy density value calculated using Weibull distribution, $W E D_{a c t}$ value shows the wind energy density calculated using actual wind speed values.

\subsubsection{Root Mean Square Error (RMSE):}

One other method used to check the accuracy of the Weibull parameter estimation methods is RMSE (Alrashidi et al., 2020).

$$
R M S E=\sqrt{\frac{1}{N} \sum_{i=1}^{n}\left(v_{i}-w_{i}\right)}
$$

Equation (14) describes $v_{i}$ as real wind speed values, $w_{i}$ as estimated values by using probability-density functions, and $n$ as the number of wind speed classes.

\subsubsection{Coefficient of Determination:}

This method is described as an equation in (15) (Alrashidi et al., 2020).

$$
R^{2}=\frac{\sum_{i=1}^{n}\left(v_{i}-\bar{v}\right)^{2}-\sum_{i=1}^{n}\left(v_{i}-w_{i}\right)^{2}}{\sum_{i=1}^{n}\left(v_{i}-\bar{v}\right)^{2}}
$$

\section{Results and Discussion}

The first comparison made is shown in Figure 2 and Figure 3. This is a comparison of the fit that the three methods provide to the actual values in the probability-density graph. 


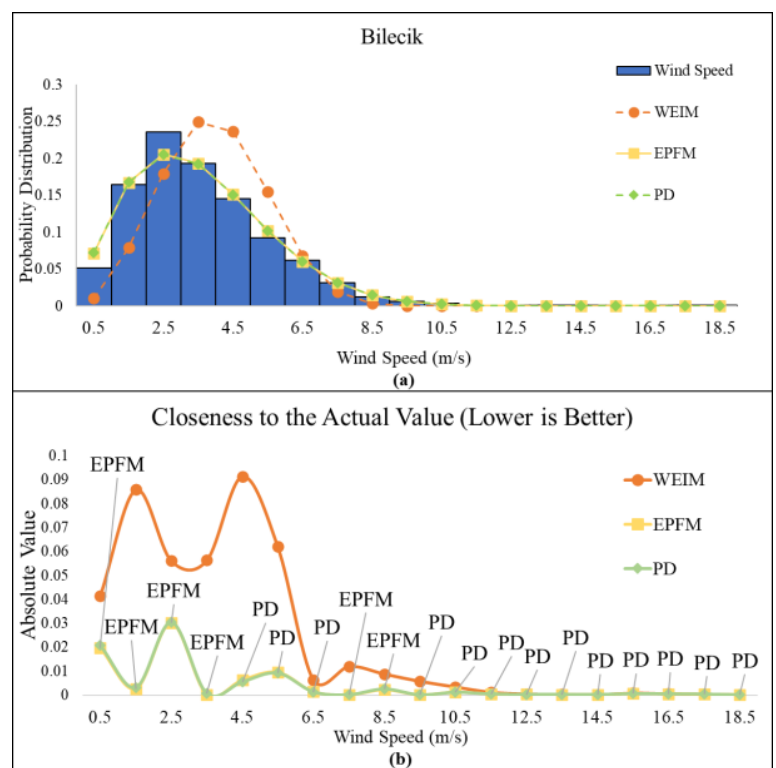

Figure 2. Comparison of the actual and Weibull distributions for Bilecik. The fit is shown in (a), the closest fit is in (b)

It can be seen from Figure 2 that WEIM has not provided a satisfactory fit. In addition, while EPFM and PD methods seem to be very close, it is the PD method that is the closest to the actual values.

Figure 3 could be seen with similar results to Figure 2. This comparison shows that for a city such as Kütahya with higher wind energy density values than Bilecik, WEIM has the closest estimation only for the lowest wind speeds. Further inspection shows the PD method being closer to the actual values.

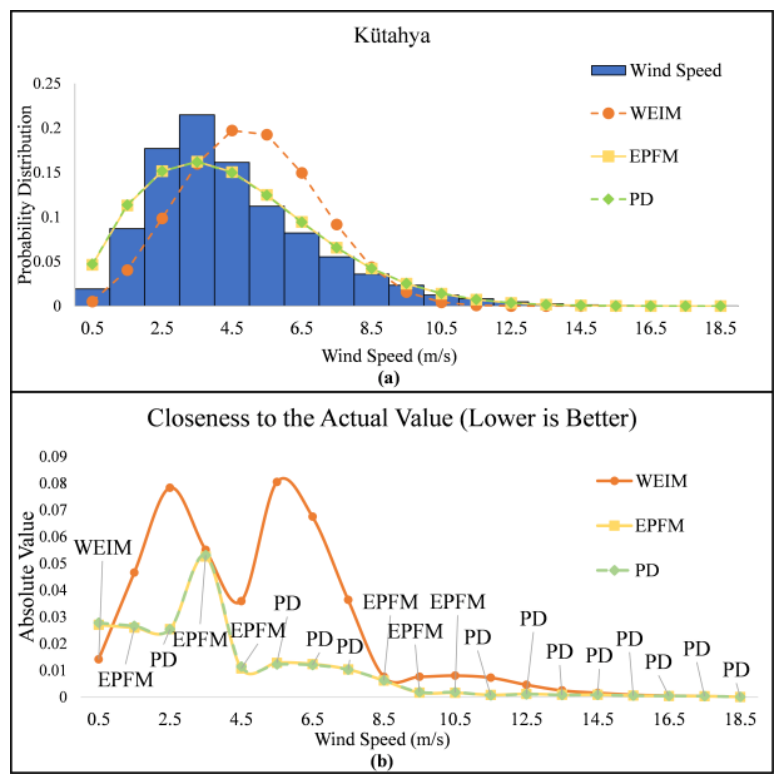

Figure 3. Comparison of the actual and Weibull distributions for Kütahya. The fit is shown in (a), the closest fit is in (b) 
In Figure 4, the calculated wind energy density values of parameter estimation methods have been compared based on their accuracy.

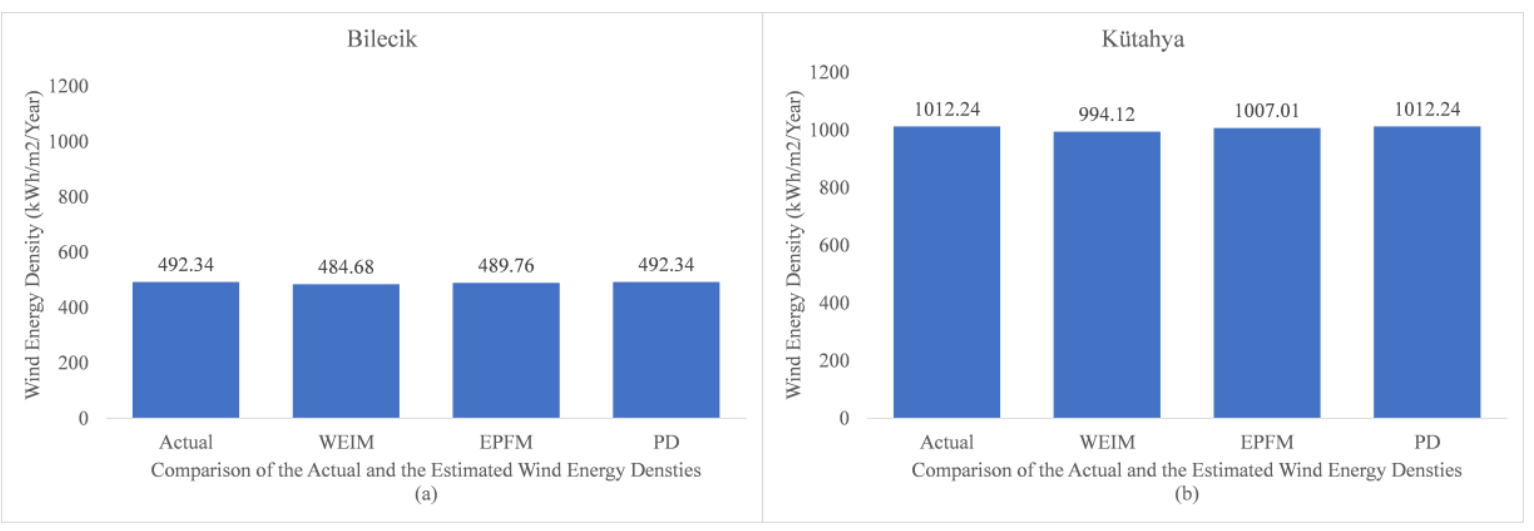

Figure 4. The comparison of the wind energy densities to the calculated values for Bilecik (a) and Kütahya (b)

Table 1 shows the calculated shape $(k)$ and scale $(c)$ values of parameter estimation methods, along with the error values. When Figure 2 and Figure 3 are inspected, it is clear that the EPFM and the PD are quite close. Although, when it comes to a general overview, the best fit has been achieved by the PD method.

Secondly, the comparison made in Figure 4 shows the PD method to be very efficient when it comes to estimating wind power densities for both cities. While the similar results of EPFM's close values to the PD method could be seen in Figure 4 as in Figure 2 and Figure 3, the best performing one in this comparison is the PD method.

Lastly, Table 1 gives the calculated scale (c) and shape (k) values of each method for both cities. The comparison made in Table 1 is ranked according to the following criteria; i) WEE value should be closer to zero, ii) RMSE value should also be close to zero (Kidmo Kaoga et al., 2014), iii) $R^{2}$ value should be closer to one (Akyuz and Gamgam, 2017). Table 2 presents the mean values which were calculated by using the data of Table 1 . This calculation has been made to better indicate the best performing method for both cities.

Table 1. The shape (k), scale (c), and error values of the parameter estimation methods

\begin{tabular}{|c|c|c|c|c|c|c|}
\hline \multirow{4}{*}{ 芦 } & & $\mathbf{k}$ & c & WEE & RMSE & $\mathbf{R}^{2}$ \\
\hline & WEIM & 2.8933 & 4.4630 & 0.0156 & 0.2824 & 0.9477 \\
\hline & EPFM & 1.8976 & 4.0158 & 0.0052 & 0.1010 & 0.9991 \\
\hline & PD & 1.8884 & 4.0152 & 8.1E-09 & 0.1021 & 0.9991 \\
\hline \multirow{4}{*}{ 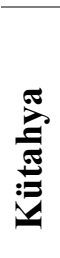 } & & $\mathbf{k}$ & c & WEE & RMSE & $\mathbf{R}^{2}$ \\
\hline & WEIM & 2.8914 & 5.6699 & 0.0179 & 0.2862 & 0.9456 \\
\hline & EPFM & 1.8900 & 5.0985 & 0.0052 & 0.1503 & 0.9959 \\
\hline & PD & 1.8810 & 5.0977 & $1.4 \mathrm{E}-08$ & 0.1513 & 0.9958 \\
\hline
\end{tabular}


Regarding these three comparisons and the results, while the PD method seems to have accurate results in predicting the wind energy density and has lower error values for WEE, the method with the fewer error values, in general, has been the EPFM. This result shows that the Energy Pattern Factor method is the better one among these three methods for the error criteria.

Table 2. The ranking of the methods based on Table 1

\begin{tabular}{l|c|c|c|c|c|c|c}
\hline \multirow{2}{*}{} & \multicolumn{2}{|c|}{ WEE } & \multicolumn{2}{c|}{ RMSE } & \multicolumn{2}{|c|}{ R$^{2}$} & \multirow{2}{*}{ Overall } \\
\cline { 2 - 7 } & Rank & Value & Rank & Value & Rank & Value & \\
\hline EPFM & 2 & $5.2 \mathrm{E}-03$ & 1 & 0.126 & 1 & 0.998 & $\mathbf{1}$ \\
\hline PD & 1 & $1.1 \mathrm{E}-08$ & 2 & 0.127 & 2 & 0.997 & $\mathbf{2}$ \\
\hline WEIM & 3 & $1.7 \mathrm{E}-02$ & 3 & 0.284 & 3 & 0.947 & $\mathbf{3}$ \\
\hline
\end{tabular}

Comparison results indicate that the recently proposed WEIM is not particularly efficient when compared to EPFM and PD methods. The comparison made in Figure 2 and Figure 3 shows that the PD method has presented accurate results, and WEIM does not provide as close results to the real wind speed data as the other two methods.

The results in calculating wind energy density suggest that while the EPFM and PD methods have very close results, the best estimation for the wind energy densities of the two cities is made by the PD method.

When the performance metric results for all three methods have been compared, the most efficient method has been EPFM, with fewer error values.

\section{Conclusion}

WEIM, EPFM, and PD methods have been compared using three factors;

i. The fit that these methods provide to the real wind speed in probability graph,

ii. The accuracy in calculating the wind energy density,

iii. The results of performance criteria for these methods.

These comparisons have given the following conclusions;

i. $\quad$ The overall best fit has been provided by the PD method.

ii. The method with the closest estimation to the actual wind energy density has been the PD method.

iii. The results of performance criteria indicate that the EPFM has fewer error values.

In conclusion, the overall result suggests that the best method to estimate Weibull parameters for Bilecik and Kütahya regions has been the PD method.

\section{References}

Akdağ, S. A., \& Dinler, A. (2009). "A new method to estimate Weibull parameters for wind energy applications.", Energy Conversion and Management, 50(7), 1761-1766. doi:10.1016/j.enconman.2009.03.020 
Akpinar, E. K., \& Akpinar, S. (2005). "An assessment on seasonal analysis of wind energy characteristics and wind turbine characteristics", Energy Conversion and Management, 46(11-12), $1848-1867$.

Akyuz, H. E., \& Gamgam, H. (2017). "Statistical analysis of wind speed data with weibull, lognormal and gamma distributions", Cumhuriyet Science Journal, 68-76.

Alrashidi, M., Rahman, S., \& Pipattanasomporn, M. (2020). "Metaheuristic optimization algorithms to estimate statistical distribution parameters for characterizing wind speeds", Renewable Energy, 149, 664-681.

Bañuelos-Ruedas, F., Angeles-Camacho, C., \& Rios-Marcuello, S. (2010). "Analysis and validation of the methodology used in the extrapolation of wind speed data at different heights", Renewable and Sustainable Energy Reviews, 14(8), 2383-2391.

Chang, T. P. (2011). "Performance comparison of six numerical methods in estimating Weibull parameters for wind energy application.”, Applied Energy, 88(1), 272-282. doi:10.1016/j.apenergy.2010.06.018

Chaurasiya, P. K., Ahmed, S., \& Warudkar, V. (2018). "Study of different parameters estimation methods of Weibull distribution to determine wind power density using ground based Doppler SODAR instrument”, Alexandria Engineering Journal, 57(4), 2299-2311.

Counihan, J. (1975). "Adiabatic atmospheric boundary layers: A review and analysis of data from the period 1880-1972", Atmospheric Environment, 9(10), 871-905.

Dokur, E., \& Kurban, M. (2015). Wind speed potential analysis based on Weibull distribution. Balkan Journal of Electrical and Computer Engineering, 3, 231-235.

Enerji Atlasi. Retrieved January 13, 2021 from https://www.enerjiatlasi.com/ruzgar-enerjisiharitasi/turkiye

Gualtieri, G., \& Secci, S. (2011). "Comparing methods to calculate atmospheric stability-dependent wind speed profiles: A case study on coastal location”, Renewable Energy, 36(8), 2189-2204.

Kidmo Kaoga, D., Doka Yamigno, S., Raidandi, D., \& Djongyang, N. (2014). "Performance analysis of Weibull methods for estimation of wind speed distributions in the adamaoua region of Cameroon", International Journal of Basic and Applied Sciences, 3(3). doi:10.14419/ijbas.v3i3.3081

Kidmo, D. K., Danwe, R., Doka, S. Y., \& Djongyang, N. (2015). "Statistical analysis of wind speed distribution based on six Weibull Methods for wind power evaluation in Garoua, Cameroon.", Revue des Energies Renouvelables, 18(1), 105-125.

MERRA. (n.d.). Retrieved January 12, 2021, from http://www.soda-pro.com/web-services/meteodata/merra

Sumair, M., Aized, T., Gardezi, S. A., Rehman, S. U., \& Rehman, S. M. (2020). "A novel method developed to estimate Weibull parameters", Energy Reports, 6, 1715-1733.

Usta, I., Arik, I., Yenilmez, I., \& Kantar, Y. M. (2018). “A new estimation approach based on moments for estimating Weibull parameters in wind power applications", Energy Conversion and Management, $164,570-578$. 